\title{
PENGARUH PENERAPAN WPS (WELDING PROCEDURE SPECIFICATION) AL 6005 TIPE BUTT JOINT TERHADAP KEKUATAN SAMBUNGAN LAS AL 6061
}

\author{
The Effect of Application WPS (Welding Procedure Specification) Al 6005 Butt Joint Type Against \\ Strength of Al 6061 Weld Joint
}

\author{
Ahmad Abi Sodik ${ }^{1}$, Nely Ana Mufarida ${ }^{2}$, Kosjoko $^{3}$ \\ 1,2,3Program Studi Teknik Mesin, Fakultas Teknik, Universitas Muhammadiyah Jember \\ Email : ${ }^{1)}$ achmadabiesodik2@gmail.com, ${ }^{2}$ nelyana_munfarida@yahoo.com
}

\begin{abstract}
ABSTRAK
Dokumen WPS (welding procedure specification) merupakan dokumen yang sangat penting dalam pengelasan masal di suatu industri. Maka dari itu penelitian ini bertujuan untuk mencari pengaruh penerapan WPS aluminium 6005 tipe butt joint terhadap pengelasan sambungan aluminium 6061 dengan posisi pengelasan $1 \mathrm{G}$ (flat) dan $3 \mathrm{G}$ (vertikal) serta pada ketebalan $3 \mathrm{~mm}, 5 \mathrm{~mm}$, dan $8 \mathrm{~mm}$ dan menggunakan filler metal ER 5356. Pengelasan aluminium 6061 ini dilakukan oleh welder bersertifikat dengan menggunakan las GTAW (gas tungsten arc welding) atau TIG (tungsten inert gas) dengan detail sambungan pengelasan single V-butt joint sudut $60^{\circ}$. pengujian material dilakukan dengan menggunakan pengujian kekuatan tarik, bending dan juga pengujian cacat dengan menggunakan radiography dan dye penetrant. Hasil penelitian ini menunjukan bahwa pengelasan aluminium 6061 dengan menggunakan WPS aluminium 6005 dengan posisi 1G menghasilkan las yang lebih baik dibandingkan posisi $3 \mathrm{G}$ dari hasil pengujian cacat luar maupun dalam. Cacat porositas terjadi pada posisi pengelasan $1 \mathrm{G}$ dengan jumlah dan ukuran yang sangat kecil sedangkan pada posisi pengelasan $3 \mathrm{G}$ terjadi cacat porositas dan incomplete fusion dengan ukuran dan jumlah di luar syarat penerimaan pengujian berdasarkan ISO. Selain pengujian cacat las, hasil dari pengujian kekuatan material las yang dilakukan dengan menggunakan uji tarik dan uji tekuk juga menunjukan kekuatan yang signifikan terjadi pada posisi pengelasan $1 \mathrm{G}$ baik material tebal $3 \mathrm{~mm}, 5 \mathrm{~mm}$ maupun tebal $8 \mathrm{~mm}$.
\end{abstract}

Kata Kunci: Aluminium 6061. Aluminium 6005. Butt Joint. WPS. Las GTAW.

\begin{abstract}
The document of WPS (welding procedure specification) is important document in mass welding in an industry. Therefore, this study aims to find the effect of applying aluminium WPS of 6005 type butt joint on welding joint aluminium 6061 with $1 G$ and $3 G$ welding positions of $3 \mathrm{~mm}, 5 \mathrm{~mm}$ and $8 \mathrm{~mm}$ thickness by using ER 5356 metal filler. Aluminium 6061 welding carried out by certified welder using GTAW welding (gas tungsten arc welding) or TIG (tungsten inert gas) with welding joint details of a single $V$ butt joint angle of $60^{\circ}$. Material testing was investigated by using tensile, bending strength, and defect testing using radiography and dye penetrant. The results of this study indicate that welding aluminium 6061 using WPS aluminium 6005 with a $1 G$ (flat) position produces a weld that is better than the $3 G$ (vertical) position as explained from the results of external and internal defects. Porosity defects occur in the welding position of $1 G$ with a very small number and size while in the welding position $3 G$ occurs porosity and fusion incomplete defects with sizes and quantities outside the ISO acceptance testing requirements. In addition to testing for weld defects, the strength of the weld material carried out by using tensile and bending test. It showed significant strength in the welding position of $1 \mathrm{G}$ both $3 \mathrm{~mm}$, $5 \mathrm{~mm}$ and $8 \mathrm{~mm}$ thickness.
\end{abstract}

Key Words: Aluminium 6061. Aluminium 6005. Butt Joint. WPS. Welding GTAW 


\section{PENDAHULUAN}

Perindustrian di Indonesia merupakan salah satu komponen yang penting, karena dengan semakin berkembangnya sector industri memungkinkan perekonomian Indonesia ikut berkembang pesat dan semakin baik, sehingga membawa perubahan dalam struktur perekonomian nasional. Tuntutan untuk mengubah perekonomian dari sektor perindustrian membuat tak sedikit industri yang juga menciptakan alternatif - alternatif untuk menciptakan produk yang lebih efisien dibanding yang telah ada. Inovasi penemuan yang berlatar belakang menambah manfaat, mempermudah penggunaan, menambah layanan, mempermudah mendapatkan dan meminimalisir waktu tempuh sangat di idam-idamkan oleh manusia di era 21 ini. Selain itu, saat ini kita hidup di era Revolusi Industri Keempat (Klaus Schwab, The Fourth Industrial Revolution, 2017). Era yang diwarnai oleh kecerdasan buatan (artificial intelligence), era super komputer, rekayasa genetika, teknologi nano, mobil otomatis, inovasi, dan perubahan yang terjadi dalam kecepatan eksponensial yang akan mengakibatkan dampak terhadap ekonomi, industri, pemerintahan, politik, bahkan membuka perdebatan atas definisi manusia itu sendiri. Era yang menegaskan dunia sebagai kampung global (Marshall McLuhan, The Gutenberg Galaxy: The Making of Typographic Man, 1962). Di Indonesia sendiri banyak sekali proyek yang menciptakan inovasi - inovasi baru baik dibidang teknologi komunikasi, informasi maupun transportasi. Salah satu proyek yang sedang berjalan saat ini adalah proyek LRT (Lintas Rel Terpadu) untuk wilayah Jabodebek. Lintas Rel Terpadu atau disingkat LRT adalah salah satu sistem kereta api penumpang yang beroperasi di kawasan perkotaan yang konstruksinya ringan dan bisa berjalan bersama lalu lintas lain atau dalam lintasan khusus (Wikipedia Indonesia). Dalam menghadapi tantangan dunia bisnis ke depan. Beberapa pembaharuan yang dilakukan oleh perusahaan kereta api adalah rangka pada carbody (rangka dalam) gerbong kereta api yang dahulu memakai bahan material yang cukup bermasa tinggi (Mild Steel) kini perusaan ini mencoba membuat kereta api yang lebih efisien dalam material carbody yaitu dengan menggunakan material aluminium. Spesifikasi aluminium secara umum yaitu sangat kuat dan memiliki ketahanan yang cukup baik terhadap penurunan suhu, tahan terhadap karat, fleksibel, tidak mudah terbakar dan tidak menghasilkan zat buangan ketika terkena panas tinggi. Aluminium sendiri termasuk material logam yang sangat ringan sehingga efektif untuk membuat komponen kereta api, dengan begitu bobot kereta juga akan relatif ringan sehingga menghasilkan kecepatan yang lebih tinggi. Tetapi dibalik semua itu, logam aluminium juga mempunyai kelemahan dalam hal penyambungan Di dalam jurnal penelitian karya Andrea Tri Wibowo dkk, dari Teknik Mesin Universitas Diponegoro yang berjudul 'Pengaruh Heat Treatment pada Aluminium alloy 6061-T6 dan Pengelasan Transversal Tungsten Inert Gas Terhadap Sifat Mekanik dan Struktur Mikro' mengatakan bahwa kelemahan aluminium adalah sifat mampu las (weldability) relatif rendah dan sambungan las rentan terhadap kegagalan (failure) karena logam aluminium sangat rentan terhadap oksidasi, sehingga dalam pengelasan aluminium dibutuhkan identifikasi sambungan las dan parameter-parameter yang tepat untuk menghasilkan hasil pengelasan yang sesuai dengan yang diharapkan. Semua aspek - aspek tersebut disatukan dalam Welding Procedure Specification (WPS) sebagai panduan untuk Welder (tukang las) dalam melakukan proses pengelasan agar hasil pengelasan sesuai dengan yang telah direncanakan. WPS hanya berlaku untuk satu spesifikasi material, akan tetapi WPS dari material lain dapat di adopsi untuk pengelasan tertentu dengan tetap melalui tahap pengujian WPS. Dalam penelitian ini akan dilakukan adopsi WPS aluminium 6005 yang telah terkualifikasi dengan baik yang akan digunakan untuk pengelasan material aluminium 6061, karena kedua material tersebut masih tergolong dalam keluarga yang sama yaitu aluminium tipe 60xx. Selain itu, kedua material aluminium ini juga memiliki karakteristik dan juga paduan yang sama.

Didalam pengerjaan proyek pembuatan carbody gerbong kereta LRT (Lintas Rel Terpadu) Jabodebek, salah satu perusahaan kereta api mempunyai masalah pada hasil kekuatan dan struktur mikro sambungan las aluminium untuk carbody gerbong kereta. Jika WPS itu dipakai untuk pedoman pengelasan di carbody kereta, maka akan mengakibatkan ketidak kuatan pada bagianbagian carbody dan pada jangka panjang bisa merusak carbody itu sendiri, terlebih lagi akan ada resiko yang ditimbulkan karena kereta ini dirancang untuk kereta penumpang. Oleh karena itu penulis membuat rumusan masalah untuk membantu dalam menyelesaikan masalah sambungan las aluminium diantaranya :

(1) Bagaimana prosedur penentuan parameter WPS (Welding Procedure Spesification) sesuai standar untuk 
pedoman pengelasan aluminium carbody gerbong kereta?

(2) Bagaimana perbedaan cacat dalam dan cacat luar pada ketebalan berbeda dan posisi pengelasan berbeda?

(3) Bagaimana perbedaan kekuatan material las pada ketebalan berbeda dan posisi pengelasan berbeda? (4) Bagaimana pengaruh penggunaan WPS Al 6005 terhadap pengelasan material $\mathrm{Al} 6061$ ?

Adapun tujuan dari penelitian ini adalah sebagai berikut:

(1) Melakukan identifikasi standar pengelasan untuk prosedur penentuan parameter WPS pengelasan sambungan aluminium Al 6061 carbody kereta.

(2) Mengetahui kecacatan dalam dan luar spesimen pengelasan.

(3) Mengetahui hasil kekuatan las dengan WPS yang telah dibuat.

(4) Mengetahui pengaruh WPS Al 6005 tipe butt joint terhadap kekuatan dan struktur mikro sambungan las Al 6061.

\section{TINJAUAN PUSTAKA}

Aluminium merupakan jenis logam yang sangat spesial dikarenakan pada lapisan aluminium terdapat lapisan oksidasi yang bisa melindungi dari korosi, selain itu aluminium juga banyak digunakan dalam pabrikasi logam untuk beberapa transportasi termasuk kereta api karena sifatnya yang ringan dan juga memiliki kekuatan yang sangat tinggi, hal ini juga disebutkan oleh beberapa ahli logam sebagai berikut:

Menurut Daryanto (2009: 3), "aluminum adalah sejenis logam yang begitu keras dan begitu kuat, aluminium mempunyai berat jenis yang rendah, yakni 2,6 dan warnanya putih kebiru-biruan."

Menurut Sumanto (2005: 46), "aluminium adalah logam yang sangat ringan (berat jenis aluminium 2,56 atau $1 / 3$ berat jenis tembaga). Tahanan jenis $2,8 \times 10^{-8}$ atau 1,25 × tahanan jenis tembaga."

Didalam buku Aluminium Association, Inc tahun 1990, tertulis bahwa aluminium merupakan unsur kimia golongan IIIA dalam sistem periodik unsur, dengan nomor atom 13 dan berat atom 26,98 gram per mol. Di dalam udara bebas aluminium mudah teroksidasi membentuk lapisan tipis oksida $\left(\mathrm{Al}_{2} \mathrm{O}_{3}\right)$ yang tahan terhadap korosi. Aluminium juga bersifat amfoter yang mampu bereaksi dengan larutan asam maupun basa (Anton J. Hartono, 1992).

Aluminium pertama kali ditemukan oleh Sir Humphey Davy dalam tahun 1809 sebagai unsur dan pertama kali direduksi sebagai logam oleh H. C.
Oersted, tahun 1825 (ASM, 2007). Secara industri tahun 1886, Paul Heroult di Perancis dan C. M. Hall di Amerika Serikat secara terpisah telah memperoleh logam aluminium dari alumina dengan cara elektrolisa dari garamnya yang terfusi. Ketika dilakukan reduksi elektrolitik alumina $\left(\mathrm{Al}_{2} \mathrm{O}_{3}\right)$ yang dilarutkan dalam cryolite cair dikembangkan secara independen oleh Charles Hall di Ohio Amerika Serikat dan Paul Heroult di Perancis pada tahun 1886, kendaraan internal dan mesin bertenaga pertama bermunculan, dari tahun inilah aluminium mulai memainkan peran sebagai bahan otomotif meningkatkan nilai rekayasa (ASM, 2001). Penelitian 'pengaruh besarnya arus listrik pengelasan' telah lakukan oleh Wardoyo dan Sumiyarso (2010), mereka menyatakan bahwa peningkatan arus listrik pada pengelasan TIG paduan aluminium 6061 T6 mengakibatkan penurunan kekuatan luluh dan kekuatan tarik maksimum. Hal ini menyatakan bahwa banyak resiko yang akan dihadapi ketika proses pengelasan material Al 6061 T6 ini.

Aluminium 6061 T6 adalah aluminium paduan yang dapat diolah dengan kekuatan sedang hingga tinggi dengan kekuatan lebih tinggi dari aluminium tipe 6005. Aluminium ini memiliki ketahanan korosi yang sangat baik dan kemampuan las yang sangat baik meskipun memiliki kelemahan kekuatan di zona las (HAZ). Aluminium ini memiliki kekuatan kelelahan sedang dan memiliki sifat dingin yang baik dalam temper T4, tetapi formability terbatas dalam temper T6. Kebanyakan dari material Al 6061-T6 di las menggunakan proses las GTAW dan GMAW dengan menggunakan filler dengan kode ER4043 dan ER5356. Aluminium murni dan aluminium paduan yang paling umum digunakan sebagai metode pengelasannya adalah menggunakan busur listrik dengan elektroda kawat yang terus menerus (dengan arus DC) atau elektroda tungsten permanen ditambah kawat pengisi (dengan arus AC). Busur dilindungi oleh gas argon (atau campuran gas argon-helium) untuk melindungi kolam las dan elektroda dari atmosfer sekitarnya ketika pengerjaan pengelasan dilakukan (Dewanto, Anggoro P. 2016).

Welding Procedure Specification atau spesifikasi prosedur las merupakan prosedur tertulis tentang pengelasan yang sudah terkualifikasi dengan baik untuk memberikan arahan untuk juru las dalam membuat pengelasan produksi (production weld) sesuai persyaratan standar yang dipakai. Prosedur ini biasanya digunakan untuk pengelasan produksi masal, sehingga dalam pengelasannya hanya menggunakan 
satu prosedur pengelasan yang sudah terkualifikasi dengan baik. WPS dapat digunakan untuk memberikan arahan kepada juru las untuk menjamin kesesuaian dengan persyaratan dari standar yang dipakai. Dalam produksi masal tidak ada pengelasan yang diizinkan tanpa kualifikasi WPS oleh Pihak Ketiga atau Badan yang dilegalkan. Kualifikasi prosedur pengelasan harus memenuhi persyaratan ASME Bagian IX dan kode yang berlaku. Heterogenisasi pengelasan heterogen juga harus memenuhi syarat sesuai dengan persyaratan ASME. Hasil penyambungan logam dengan logam ferrous maupun nonferrous melalui pengelasan sangat diharapkan akan mengahasilkan sambungan yang berkualitas dari segi kekuatan dan lapisan las dari bahan atau logam yang dilas, di mana untuk menghasilkan sambungan las yang berkualitas hendaknya kedua ujung/bidang atau bagian logam yang akan dilas perlu di berikan suatu bentuk kampuh las tertentu. Untuk memperoleh kekuatan hasil pengelasan yang dapat di jamin kualitasnya, pengelasan sebaiknya menggunakan berbagai bentuk kampuh yang sudah dikembangkan dan telah distandarkan. Sambungan butt joint adalah jenis sambungan tumpul, dalam aplikasinya jenis sambungan ini terdapat berbagai macam jenis kampuh atau groove diantaranya $V$ groove (kampuh V), single bevel, J groove, U Groove, Square Groove untuk melihat macam macam kampuh las lebih detail lihat gambar berikut ini:

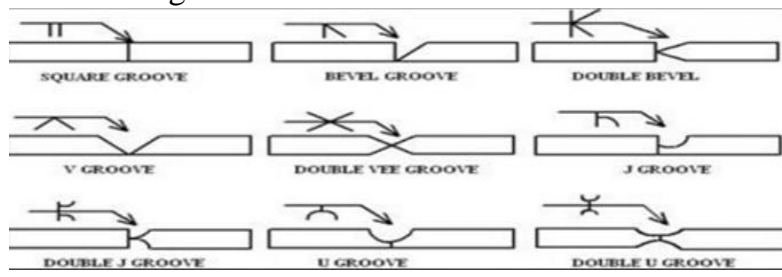

Gambar 1. Macam-macam kampuh butt joint

Untuk memastikan bahwa WPS yang telah distandarkan memiliki kekuatan sesuai dengan yang di inginkan, maka WPS harus diuji terlebih dahulu untuk memastikan kekuatan sambungan dengan yang telah di syaratkan dalam buku standar. Pengujian-pengujian ini dilakukan untuk memastikan bahwa standar dari parameter pengelasan telah benar dan menghasilkan hasil uji sesuai dengan yang telah distandarkan. Secara garis besar metode pengujian las terbagi menjadi dua yaitu Destruktif Test (DT) dan Non Destruktif Test (NDT).

\section{METODE PENELITIAN}

Penelitian ini dilakukan di Laboratoria Teknik Produksi Institut Teknologi Bandung (ITB) bersama tim WPS dari Pusat Pengembangan Teknologi dan Industri Perkeretaapian yaitu kerjasama antara Fakultas Teknik Mesin dan Dirgantara Institut Teknologi Bandung dan Kementerian Perindustrian selama 4 bulan, mulai dari 4 September 2018 sampai selesai.

Pengumpulan data diperoleh dari buku-buku welding, jurnal internasional welding dan aluminium, modul, artikel, dan melalui internet. Sehingga dapat mempelajari karakteristik material aluminium 6061 secara detail, tipe pengelasan dan sambungan, serta mempelajari pengujian-pengujian las. Objek yang menjadi fokus penelitian adalah Aluminium tipe 6061 T6, aluminium jenis ini merupakan yang banyak digunakan pada fabrikasi kendaraan transportasi seperti kereta api. Aluminium 6061-T6 adalah aluminium 6061 dalam temper T6. Bahan pengisi yang digunakan adalah AWS ER 5356 yang memberikan kecocokan warna yang lebih baik di mana perakitan yang dilas harus dianodisasi. Pada penelitian ini akan dilakukan untuk analisa pengaruh penggunaan WPS Aluminium 6005 terhadap hasil pengelasan sambungan Aluminium 6061 carbody gerbong kereta. Penyesuaian standar parameter-parameter pengelasan dilakukan dengan menggunakan standar pengelasan internasional ISO (International Standard Organization).

1. Identifikasi Sambungan Las

Dalam hal ini, perlu diperhatikan aspek-aspek standar pada pengelasan aluminium, di bawah ini merupakan aspek yang harus diperhatikan yang bersumber dari badan standarisasi yaitu ISO dan AWS:

a) WPS (Welder Procedure Specification)

a. Jenis Welding Process dan Thickness

b. Jenis Elektroda dan Filler/ Bahan Tambah

c. Posisi Pengelasan

b) WPQR (Welder Procedure Qualification Record) 2. Identifikasi sambungan las pada Carbody

Identifikasi material, tipe welding dan letak material sambungan pada Carbody LRT PT. INKA berdasarkan standarisasi international welding untuk material aluminium Al 6061 T6 tipe plat dan tipe profil. 3. Penentuan parameter sambungan las carbody

Dalam sambungan las ada beberapa parameter diantaranya Thickness, Welding Process, Position dan Filler yang penting untuk diketahui dan harus sesuai dengan standar yang telah ditentukan, karena parameter ini merupakan petunjuk bagi welder dalam pelaksanaan pengelasan di workshop.

\section{Proses Pengelasan Material Uji}

Pada pengujian WPS ini pengelasan yang digunakan adalah las GTAW (Gas Tungsten Arc 
Welding) atau Pengelasan TIG (Tungsten Inert Gas) dengan menggunakan Gas Argon $100 \%$ dan Filler Metal AWS ER 5356 ( $3 \mathrm{~mm}$ ) serta posisi pengelasan Flat (1G) / PA. Pengelasan TIG pada material aluminum ini didasarkan pada standar AWS D.1.2/ D
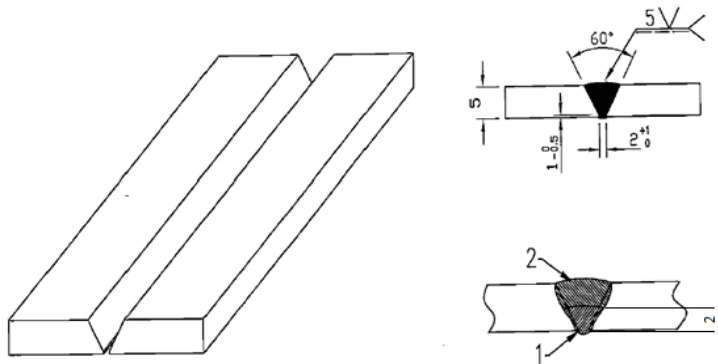

1.2M : 2003 yakni bentuk sambungan $\mathrm{V}$ tunggal (single-V-groove weld):

Gambar 2. Bentuk Sambungan Pengelasan

Keterangan:

a) Bentuk Alur: Alur V

Tunggal

e) Size Of Weld: $3,5,8 \mathrm{~mm}$

b) Panjang Spesimen: 200

$\mathrm{mm}$

f) Root Face: $1 \mathrm{~mm}$

g) Layer: $2 \mathrm{~mm}$

c) Tebal Material: $3,5,8 \mathrm{~mm}$

d) Root Opening: $2 \mathrm{~mm}$

h) Groove Angle: $60^{\circ}$

Parameter Pengelasan :
a) Tipe Arus : AC
d) Logam Pengisi
b) Arus : $125-135$
Amp
(Filler) : AWS ER 5356

c) Gas

Tipe : Argon 100\%

Aliran : 10-15 L/menit

e) Posisi Pengelasan : $1 \mathrm{G}$ (Flat up) dan 3G (Vertical up)

Dimensi ukuran spesimen

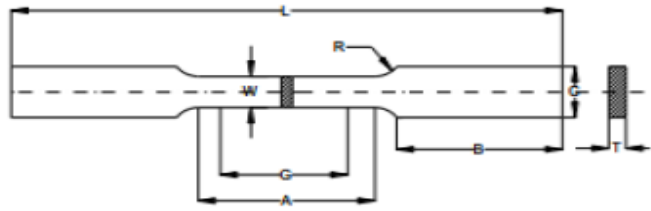

Gambar 3. Bentuk spesimen pengujian tarik(ASME) Keterangan :

\begin{tabular}{ll} 
Gage length $(\mathrm{G})$ & $: 40-50 \mathrm{~mm}$ \\
Width $(\mathrm{W})$ & $: 10-12 \mathrm{~mm}$ \\
Length of reduced section $(\mathrm{A})$ & $: 57 \mathrm{~mm}$ \\
Thickness $(\mathrm{T})$ & $: 3,5,8 \mathrm{~mm}$ \\
Radius of fillet $(\mathrm{R})$ & $: 10-12$ \\
Overall length & $: 200 \mathrm{~mm}$ \\
\hline & \\
\hline
\end{tabular}

Gambar 4. Bentuk spesimen pengujian tekuk (ASME) Keterangan :

Width (W) : $40-50 \mathrm{~mm}$
Length of reduced section (A) : $57 \mathrm{~mm}$

Thickness (T)

$: 3,5,8 \mathrm{~mm}$

Overall length

: $200 \mathrm{~mm}$

\section{Diagram Tegangan Renggangan}
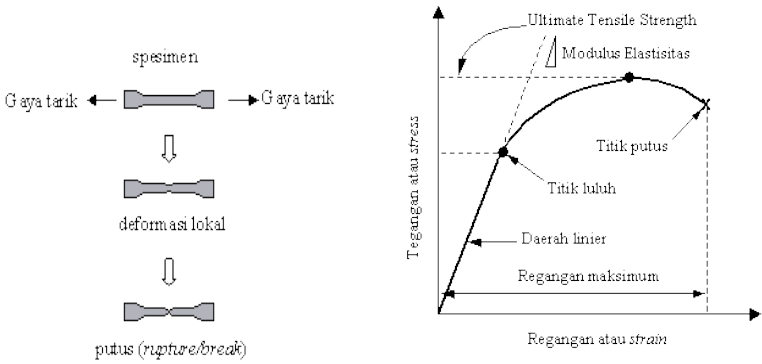

Gambar 5. Diagram Tegangan Renggangan

Variabel Pengujian

a) Pengujian Visual Examination

Tabel 1. Variabel Pengujian Visual

\begin{tabular}{|c|c|c|c|c|}
\hline Material & Posisi & Tebal & $\begin{array}{c}\text { Uji } \\
\text { Face }\end{array}$ & Uji Root \\
\hline Aluminium & $1 \mathrm{G}$ & $3 \mathrm{~mm}$ & $\mathrm{P}, \mathrm{Crk}$ & $\begin{array}{c}\text { IP, } \mathrm{P}, \\
\text { Crk }\end{array}$ \\
\hline Aluminium & $3 \mathrm{G}$ & $3 \mathrm{~mm}$ & $\mathrm{P}, \mathrm{Crk}$ & $\begin{array}{c}\mathrm{IP}, \mathrm{P}, \\
\text { Crk }\end{array}$ \\
\hline Aluminium & $1 \mathrm{G}$ & $5 \mathrm{~mm}$ & $\mathrm{P}, \mathrm{Crk}$ & $\begin{array}{c}\mathrm{IP}, \mathrm{P}, \\
\text { Crk }\end{array}$ \\
\hline Aluminium & $3 \mathrm{G}$ & $5 \mathrm{~mm}$ & $\mathrm{P}, \mathrm{Crk}$ & $\begin{array}{c}\mathrm{IP}, \mathrm{P}, \\
\text { Crk }\end{array}$ \\
\hline Aluminium & $1 \mathrm{G}$ & $8 \mathrm{~mm}$ & $\mathrm{P}, \mathrm{Crk}$ & $\begin{array}{c}\mathrm{IP}, \mathrm{P}, \\
\text { Crk }\end{array}$ \\
\hline Aluminium & $3 \mathrm{G}$ & $8 \mathrm{~mm}$ & $\mathrm{P}, \mathrm{Crk}$ & $\begin{array}{c}\mathrm{IP}, \mathrm{P}, \\
\text { Crk }\end{array}$ \\
\hline
\end{tabular}

Ket: IP (Incomplete Penetration), P (Porosity), Crk (Crack)

b) Pengujian Radiography Test

Tabel 2. Variabel Pengujian Radiography

\begin{tabular}{|c|c|c|c|}
\hline Material & $\begin{array}{c}\text { Posisi } \\
\text { Pengelasan }\end{array}$ & Tebal & \multirow{2}{*}{ Uji Las } \\
\hline Aluminium & $1 \mathrm{G}$ & $3 \mathrm{~mm}$ & \\
\hline Aluminium & $3 \mathrm{G}$ & $3 \mathrm{~mm}$ & \multirow{2}{*}{ IF, P } \\
\cline { 1 - 2 } Aluminium & $1 \mathrm{G}$ & $5 \mathrm{~mm}$ & IF, P \\
\hline Aluminium & $3 \mathrm{G}$ & $5 \mathrm{~mm}$ & \\
\hline Aluminium & $1 \mathrm{G}$ & $8 \mathrm{~mm}$ & \\
\hline Aluminium & $3 \mathrm{G}$ & $8 \mathrm{~mm}$ & \\
\hline
\end{tabular}

Ket: IF (Incomplete Fusion), P (Porosity)

c) Pengujian Dye Penetrant Test

Tabel 3. Variabel Pengujian Dye Penetrant Test

\begin{tabular}{|c|c|c|c|c|}
\hline Material & $\begin{array}{c}\text { Posisi } \\
\text { Pengelasan }\end{array}$ & Tebal & $\begin{array}{c}\text { Uji } \\
\text { Face }\end{array}$ & Uji Root \\
\hline Aluminium & $1 \mathrm{G}$ & $3 \mathrm{~mm}$ & $\begin{array}{c}\mathrm{IF}, \mathrm{P}, \\
\text { Crk }\end{array}$ & IP, P, Crk \\
\hline Aluminium & $3 \mathrm{G}$ & $3 \mathrm{~mm}$ & $\begin{array}{c}\mathrm{IF}, \mathrm{P}, \\
\mathrm{Crk}\end{array}$ & IP, P, Crk \\
\hline Aluminium & $1 \mathrm{G}$ & $5 \mathrm{~mm}$ & $\begin{array}{c}\mathrm{IF}, \mathrm{P}, \\
\mathrm{Crk}\end{array}$ & IP, P, Crk \\
\hline Aluminium & $3 \mathrm{G}$ & $5 \mathrm{~mm}$ & $\begin{array}{c}\mathrm{IF}, \mathrm{P}, \\
\mathrm{Crk}\end{array}$ & IP, P, Crk \\
\hline
\end{tabular}




\begin{tabular}{|c|c|c|c|c|}
\hline Aluminium & $1 \mathrm{G}$ & $8 \mathrm{~mm}$ & $\begin{array}{c}\mathrm{IF}, \mathrm{P}, \\
\mathrm{Crk}\end{array}$ & IP, P, Crk \\
\hline Aluminium & $3 \mathrm{G}$ & $8 \mathrm{~mm}$ & $\begin{array}{c}\mathrm{IF}, \mathrm{P}, \\
\mathrm{Crk}\end{array}$ & $\mathrm{IP}, \mathrm{P}, \mathrm{Crk}$ \\
\hline
\end{tabular}

Ket: IF (Incomplete Fusion), IP (Incomplete Penetration), P (Porosity), Crk (Crack)

d) Pengujian Tarik

Tabel 4. Variabel Pengujian Tarik

\begin{tabular}{|c|c|c|c|}
\hline Material & $\begin{array}{c}\text { Posisi } \\
\text { Pengelasan }\end{array}$ & Tebal & Uji Las \\
\hline Aluminium & $1 \mathrm{G}$ & $3 \mathrm{~mm}$ & \multirow{2}{*}{$\begin{array}{c}\text { Tegangan } \\
\text { Maksimum, }\end{array}$} \\
\cline { 1 - 3 } Aluminium & $3 \mathrm{G}$ & $3 \mathrm{~mm}$ & $\begin{array}{c}\text { Renggangan } \\
\text { Maksimum dan } \\
\text { Area Patah }\end{array}$ \\
\hline Aluminium & $1 \mathrm{G}$ & $5 \mathrm{~mm}$ & \\
\hline Aluminium & $3 \mathrm{G}$ & $5 \mathrm{~mm}$ & \\
\cline { 1 - 2 } Aluminium & $1 \mathrm{G}$ & $8 \mathrm{~mm}$ & \\
\cline { 1 - 2 } Aluminium & $3 \mathrm{G}$ & $8 \mathrm{~mm}$ & \\
\hline
\end{tabular}

e) Pengujian Tekuk

Tabel 5. Variabel Pengujian Tekuk

\begin{tabular}{|c|c|c|c|c|}
\hline Material & $\begin{array}{c}\text { Posisi } \\
\text { Pengelasa } \\
\text { n }\end{array}$ & $\begin{array}{c}\text { Teba } \\
1\end{array}$ & Uji Face & Uji Root \\
\hline $\begin{array}{c}\text { Aluminiu } \\
\mathrm{m}\end{array}$ & $1 \mathrm{G}$ & $\begin{array}{c}3 \\
\mathrm{~mm}\end{array}$ & \multirow{6}{*}{$\begin{array}{c}\text { Tegangan } \\
\text { Maksimu } \\
\mathrm{m} \\
\text { dan } \\
\text { Area Patah }\end{array}$} & \multirow{6}{*}{$\begin{array}{c}\text { Tegangan } \\
\text { Maksimu } \\
\text { m dan } \\
\text { Area Patah }\end{array}$} \\
\hline $\begin{array}{c}\text { Aluminiu } \\
\mathrm{m}\end{array}$ & $3 \mathrm{G}$ & $\begin{array}{c}3 \\
\mathrm{~mm}\end{array}$ & & \\
\hline $\begin{array}{c}\text { Aluminiu } \\
\mathrm{m}\end{array}$ & $1 \mathrm{G}$ & $\begin{array}{c}5 \\
\mathrm{~mm}\end{array}$ & & \\
\hline $\begin{array}{c}\text { Aluminiu } \\
\mathrm{m}\end{array}$ & $3 \mathrm{G}$ & $\begin{array}{c}5 \\
\mathrm{~mm}\end{array}$ & & \\
\hline $\begin{array}{c}\text { Aluminiu } \\
\mathrm{m}\end{array}$ & $1 \mathrm{G}$ & $\begin{array}{c}8 \\
\mathrm{~mm}\end{array}$ & & \\
\hline $\begin{array}{c}\text { Aluminiu } \\
\mathrm{m}\end{array}$ & $3 \mathrm{G}$ & $\begin{array}{c}8 \\
\mathrm{~mm}\end{array}$ & & \\
\hline
\end{tabular}

\section{HASIL DAN PEMBAHASAN}

Tabel 6. Pengujian visual

\begin{tabular}{|c|c|c|c|}
\hline Tebal & $\begin{array}{c}\text { Posisi } \\
\text { pengelasan }\end{array}$ & Cacat Las & Status \\
\hline \multirow[t]{2}{*}{$\begin{array}{c}3 \\
\mathrm{~mm}\end{array}$} & E & $\begin{array}{l}\text { Cacat las terjadi pada } \\
\text { bagian kedua ujung } \\
\text { lasan, dikarenakan } \\
\text { ketidak sesuaian panas } \\
\text { yang terjadi. Bagian } \\
\text { selain kedua ujung } \\
\text { tidak terjadi cacat. }\end{array}$ & Diterima \\
\hline & & $\begin{array}{l}\text { Cacat las terjadi pada } \\
\text { bagian kedua ujung } \\
\text { lasan, dikarenakan } \\
\text { ketidak sesuaian panas } \\
\text { yang terjadi.Bagian } \\
\text { selain kedua ujung } \\
\text { tidak terjadi cacat. }\end{array}$ & Diterima \\
\hline $\begin{array}{c}5 \\
\mathrm{~mm}\end{array}$ & $1 \mathrm{G}$ & $\begin{array}{l}\text { Cacat las terjadi pada } \\
\text { bagian kedua ujung } \\
\text { lasan, dikarenakan } \\
\text { ketidak sesuaian panas } \\
\text { yang terjadi. Bagian } \\
\text { selain kedua ujung } \\
\text { tidak terjadi cacat. }\end{array}$ & Diterima \\
\hline
\end{tabular}
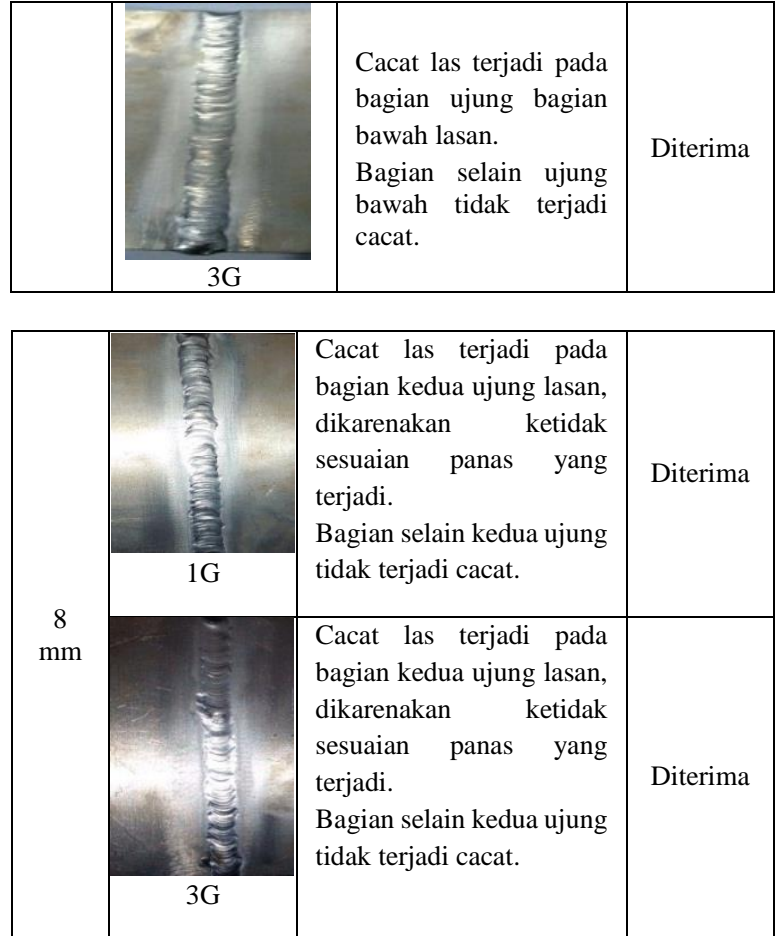

Dari keseluruhan pengujian visual menunjukan bahwa cacat rata-rata terjadi pada awal dan akhir proses pengelasan. Cacat yang terjadi merupakan cacat corner melt dan juga end melt dengan intensitas yang sangat kecil yaitu kurang dari 0,6 mm. Dijelaskan dalam Welder Visual Inspection Handbook Tahun 2013 bahwa coner dan end melt terjadi karena ketidaksesuaian panas yang terjadi pada material dan juga elektroda las, pada awal pengelasan keadaan material logam aluminium dalam keadaan dingin kemudian elektroda panas dari tungsten TIG diberikan untuk mencairkan logam pengisi, sedangkan pada akhir pengelasan keadaan material logam aluminium cukup panas sehingga ketika diberikan panas dari elektroda tungsten TIG mengakibatkan cacat terbentuk. Sesuai kode penerimaan pengujian visual EN ISO 6520-1 bahwa pada visual examination tidak terjadi Incomplete Penetration (IP) dan Incomplete Fusion (IF) maka meterial dinyatakan DITERIMA pada pengujian visual. Tabel 7. Hasil Pengujian RT Butt Joint 3 mm $1 \mathrm{G}$

\begin{tabular}{|c|c|c|c|c|c|c|c|}
\hline \multirow{2}{*}{ Part } & \multirow{2}{*}{ Lokasi } & \multicolumn{2}{|c|}{ Densitas } & \multicolumn{4}{|c|}{ Cacat } \\
\hline & & Min & $\operatorname{Max}$ & IF & IP & \begin{tabular}{|l|l|}
$\mathrm{P}$ & $\mathrm{Inc}$ \\
\end{tabular} & Crk \\
\hline \multirow{2}{*}{$\begin{array}{l}\text { Butt } \\
\text { Joint } \\
3 \mathrm{~mm}\end{array}$} & A-B & 2,58 & 2,79 & - & & - & - \\
\hline & \multicolumn{7}{|c|}{$\begin{array}{c}\text { ITB BJT-2-1G SB239-6061 T3MM261218 } \\
1 \text { A } 6\end{array}$} \\
\hline $1 \mathrm{G}$ & A & & & & & & $B$ \\
\hline
\end{tabular}


Tabel 8. Hasil Pengujian RT Butt Joint 3 mm 3G

\begin{tabular}{|c|c|c|c|c|c|c|c|}
\hline \multirow{2}{*}{ Part } & \multirow{2}{*}{ Lokasi } & \multicolumn{2}{|c|}{ Densitas } & \multicolumn{4}{|c|}{ Cacat } \\
\hline & & Min & Max & \begin{tabular}{l|l|} 
IF & IP
\end{tabular} & $\mathrm{P}$ & Inc & Crk \\
\hline \multirow{2}{*}{$\begin{array}{l}\text { Butt } \\
\text { Joint }\end{array}$} & A-B & 2,41 & 2,74 & & - & - & - \\
\hline & \multicolumn{7}{|c|}{ ITB BJT-1-3G SB20986061 T3MM261218 } \\
\hline $\mathrm{mm}$ & & & & & & & $\mathbf{B}$ \\
\hline $3 \mathrm{G}$ & & & & & & & \\
\hline
\end{tabular}

Tabel 9. Hasil Pengujian RT Butt Joint 5 mm 1G

\begin{tabular}{|c|c|c|c|c|c|c|c|c|}
\hline \multirow{2}{*}{ Part } & \multirow{2}{*}{ Lokasi } & \multicolumn{2}{|c|}{ Densitas } & \multicolumn{5}{|c|}{ Cacat } \\
\hline & & Min & Max & IF & IP & $P$ & Inc & Crk \\
\hline $\begin{array}{l}\text { Butt } \\
\text { Joint }\end{array}$ & A-B & 2,51 & 2,86 & - & - & - & - & - \\
\hline $\begin{array}{c}\text { Joint } \\
5\end{array}$ & \multicolumn{8}{|c|}{ ITB BJT-4-1G SB289-6061 T5MM 261218} \\
\hline $\mathrm{mm}$ & A & & & & & & & $B$ \\
\hline
\end{tabular}

Tabel 10. Hasil Pengujian RT Butt Joint 5 mm 3G

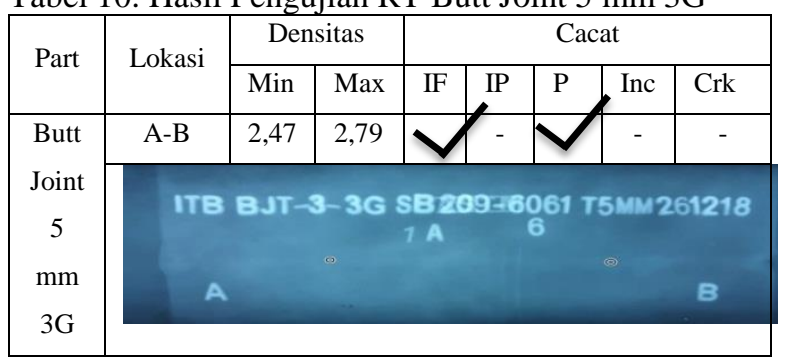

Tabel 11. Hasil Pengujian RT Butt Joint 8 mm 1G

\begin{tabular}{|c|c|c|c|c|c|c|c|}
\hline \multirow{2}{*}{ Part } & \multirow{2}{*}{ Location } & \multicolumn{2}{|c|}{ Densitas } & \multicolumn{4}{|c|}{ Cacat } \\
\hline & & Min & Max & IF & IP & \begin{tabular}{l|l}
$\mathrm{P}$ & $\mathrm{Inc}$ \\
\end{tabular} & Crk \\
\hline \multirow{2}{*}{$\begin{array}{l}\text { Butt } \\
\text { Joint }\end{array}$} & A-B & 2,49 & 2,81 & - & - & - & - \\
\hline & \multirow{2}{*}{\multicolumn{7}{|c|}{ ITB BJT-6-1G $532239=6061$ T8MM261218 }} \\
\hline 8 & & & & & & & \\
\hline $\begin{array}{c}\mathrm{mm} \\
1 \mathrm{G}\end{array}$ & & & & & & & B \\
\hline
\end{tabular}

Tabel 12. Hasil Pengujian RT Butt Joint 8 mm 3G

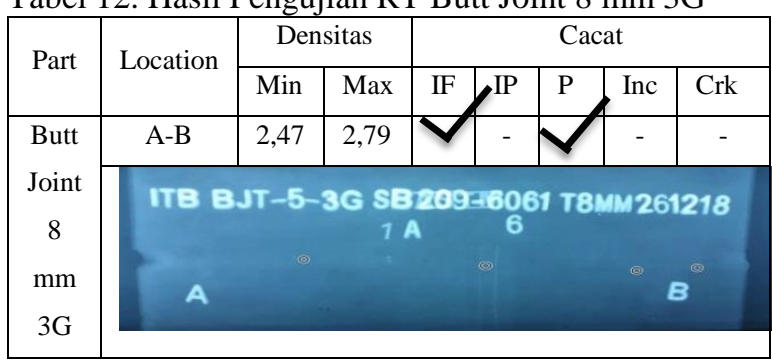

Dari tabel diatas menunjukan densitas terkecil terjadi pada material $3 \mathrm{~mm}$ dengan posisi $3 \mathrm{G}$ dengan intensitas sinar yang di terima oleh film hanya 2,41 (satuan sinar) hal ini menyatakan bahwa kepadatan weld metal pada material $3 \mathrm{~mm}$ tergolong rendah dibandingkan dengan material yang lain. Sedangkan densitas terbesar terjadi pada material $5 \mathrm{~mm}$ dengan posisi $1 \mathrm{G}$ yang menunjukan angka densitas cahaya sebesar 2,86 yang menunjukan bahwa kepadatan weld metal jauh lebih padat dibandingkan material lainnya.

Hasil pengujian Radiography menunjukan perbedaan yang signifikan terhadap posisi pengelasan. Pada posisi pengelasan 1G (Flat) menunjukan densitas minimal dan maksimal di atas persyaratan penerimaan radiography test yaitu densitas di antara 2,00 - 4,00 dan pada posisi $1 \mathrm{G}$ cacat weld metal area internal lasan sangat kecil dan masih memenuhi persyaratan penerimaan radiography test menurut EN ISO 6520-1. Namun, cacat weld metal area internal lasan pada posisi $3 \mathrm{G}$ ini menunjukan cacat yang cukup banyak meliputi Incomplete Fusion (IF) dan Porosity (P) yang dalam persyaratan penerimaan tidak diperkenankan untuk diterima karena cacat yang terjadi diatas ukuran dan jumlah syarat cacat yang telah ditentukan.

Tabel 13. Hasil pengujian dye penetrant

\begin{tabular}{|c|c|c|c|}
\hline Part & Lokasi Cacat & Cacat & Ukuran Cacat \\
\hline \multirow{2}{*}{$\begin{array}{c}3 \\
\mathrm{~mm} \\
1 \mathrm{G}\end{array}$} & Face & $\mathrm{P}$ & $1,3 \mathrm{~mm}$ \\
\hline & Root & $\mathrm{P}$ & $1,2 \mathrm{~mm}$ \\
\hline \multirow{2}{*}{$\begin{array}{c}3 \\
\mathrm{~mm} \\
3 \mathrm{G}\end{array}$} & Face & $\mathrm{P}$ & $1,2 \mathrm{~mm}$ \\
\hline & Root & IF & - \\
\hline \multirow{2}{*}{$\begin{array}{c}5 \\
\mathrm{~mm} \\
1 \mathrm{G}\end{array}$} & Face & $\mathrm{P}$ & $1 \mathrm{~mm}$ \\
\hline & Root & $\mathrm{P}+\mathrm{IF}$ & $0,8 \mathrm{~mm}$ \\
\hline \multirow{2}{*}{$\begin{array}{c}5 \\
\mathrm{~mm} \\
3 \mathrm{G}\end{array}$} & Face & - & - \\
\hline & Root & $\mathrm{P}+\mathrm{IF}$ & - \\
\hline \multirow{2}{*}{$\begin{array}{c}8 \\
\mathrm{~mm} \\
1 \mathrm{G}\end{array}$} & Face & - & - \\
\hline & Root & $\mathrm{P}$ & $0,4 \mathrm{~mm}$ \\
\hline \multirow{2}{*}{$\begin{array}{c}8 \\
\mathrm{~mm} \\
3 \mathrm{G}\end{array}$} & Face & - & - \\
\hline & Root & IF & - \\
\hline \multicolumn{4}{|c|}{ Sketch: } \\
\hline
\end{tabular}

Dari hasil pengujian cairan penetrant menunjukan rata-rata material mengalami cacat permukaan baik posisi pengelasan $1 \mathrm{G}$ maupun posisi pengelasan $3 \mathrm{G}$, discontinuity atau cacat yang terjadi pada material berupa porositas pada wajah dan juga akar las dan juga incomplete fusion yang hanya terletak pada akar las. Porositas terbesar terjadi pada wajah las material $3 \mathrm{~mm}$ posisi pengelasan $1 \mathrm{G}$ dengan ukuran diameter porositas mencapai $1,3 \mathrm{~mm}$ sedangkan pada wajah las material lain terjadi porositas dengan ukuran diameter $1,2 \mathrm{~mm}$ bahkan pada material $5 \mathrm{~mm}$ posisi $3 \mathrm{G}$ dan juga material $8 \mathrm{~mm}$ dengan kedua posisi pengelasannya tidak terjadi 
porositas. Incomplete Fusion terjadi hanya pada akar lasan dan cenderung terjadi pada posisi pengelasan $3 \mathrm{G}$ dengan ukuran yang sangat kecil, cacat incomplete fusion terjadi pada material $5 \mathrm{~mm}$ posisi $3 \mathrm{G}$ dan juga 8 mm posisi $3 \mathrm{G}$. Standar penerimaan pengujian cairan penetran yang tertera dalam buku 'Guide to Weld Inspection for Struktural Steelwork' karya The British Constructional Steelwork Association Limited ISBN 10: 1-85073-064-4 menunjukan bahwa kapasitas porositas yang terjadi pada semua tipe sambungan akan diterima jika diameter tidak lebih dari $2 \mathrm{~mm}$ dengan jumlah kurang dari 5 lubang dari rentang panjang material $100 \mathrm{~mm}$ dengan arah transversal dan kurang dari 10 lubang untuk rentang panjang material $100 \mathrm{~mm}$ dengan arah longitudinal. Sedangkan Incomlete Fusion yang terjadi pada wajah lasan tidak ada toleransi penerimaan pada tipe sambungan apapun, sedangkan Incomplete Fusion yang terjadi pada akar lasan tipe sambungan butt joint akan diterima ketika cacat yang terjadi kurang dari $3 \mathrm{~mm}$ dan ukuran cacat keseluruhan tidak lebih dari 1,5 thickness pada rentang jarak 100 mm untuk arah transversal, dan cacat kurang dari $3 \mathrm{~mm}$ dengan jumlah keseluruhan cacat tak lebih dari 3 thickness pada rentang jarak $100 \mathrm{~mm}$. 1

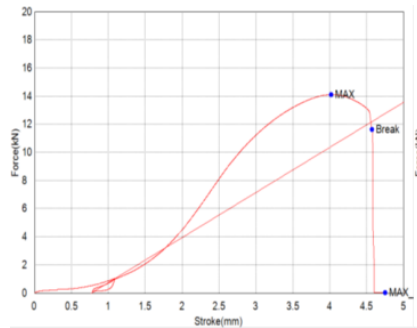

3

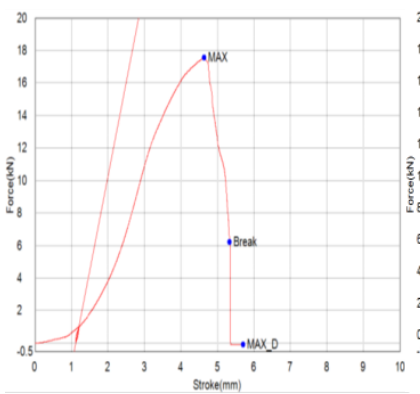

5

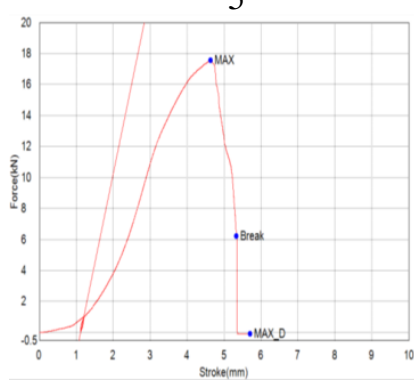

Gambar 6 Kurva Uji Tarik

Tabel 14. Analisis data uji tarik

\begin{tabular}{|c|c|c|c|c|c|}
\hline No & Part & Posisi & $\begin{array}{c}\text { Tegangan } \\
\text { Maksimum }\end{array}$ & $\begin{array}{c}\text { Renggangan } \\
\text { Maksimum }\end{array}$ & Patah \\
\hline 1 & $3 \mathrm{~mm}$ & $1 \mathrm{G}$ & $14,1100 \mathrm{kN}$ & $4,7 \mathrm{~mm}$ & Base \\
\hline 2 & $5 \mathrm{~mm}$ & $1 \mathrm{G}$ & $19,6214 \mathrm{kN}$ & $10,45 \mathrm{~mm}$ & Base \\
\hline 3 & $8 \mathrm{~mm}$ & $1 \mathrm{G}$ & $28,7149 \mathrm{kN}$ & $14,7 \mathrm{~mm}$ & Base \\
\hline 4 & $3 \mathrm{~mm}$ & $3 \mathrm{G}$ & $14,8143 \mathrm{kN}$ & $4,86 \mathrm{~mm}$ & Base \\
\hline 5 & $5 \mathrm{~mm}$ & $3 \mathrm{G}$ & $17,5447 \mathrm{kN}$ & $5,4 \mathrm{~mm}$ & Weld \\
\hline 6 & $8 \mathrm{~mm}$ & $3 \mathrm{G}$ & $16,6155 \mathrm{kN}$ & $4,1 \mathrm{~mm}$ & Weld \\
\hline
\end{tabular}

Dari tabel diatas menunjukan bahwa kekuatan tarik menunjukan hasil yang baik pada material $8 \mathrm{~mm}$ posisi pengelasan $1 \mathrm{G}$ dengan tegangan maksimum berada pada angka $28,7 \mathrm{kN}$ dan renggangan mencapai angka $14,7 \mathrm{~mm}$ serta material patah pada base metal. Sedangkan kekuatan tarik menunjukan hasil yang buruk pada material $8 \mathrm{~mm}$ posisi pengelasan $3 \mathrm{G}$ dengan tegangan maksimum hanya mencapai angka 16,6 kN dan renggangan maksimum hanya menunjukan angka 4,1 mm serta material patah pada bagian weld metal. Selain itu, pada material uji yang lain material uji dengan posisi pengelasan $1 \mathrm{G}$ rata-rata menunjukan hasil yang baik dengan keadaan material patah pada bagian base metal. Sedangkan pada material posisi pengelasan 3G, dua diantara tiga material uji mengalami patah pada bagian weld metal.
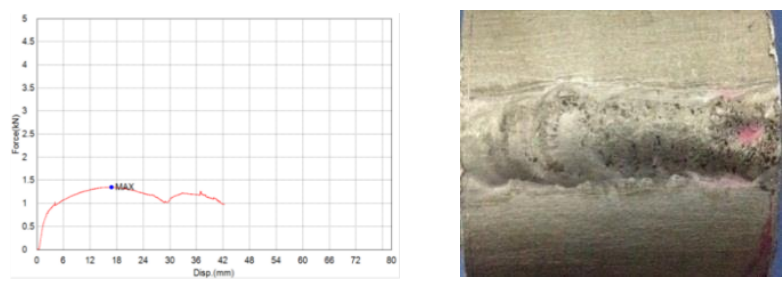

4

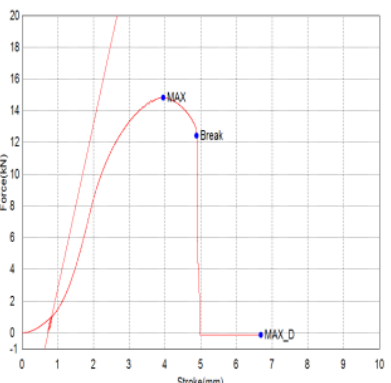

6
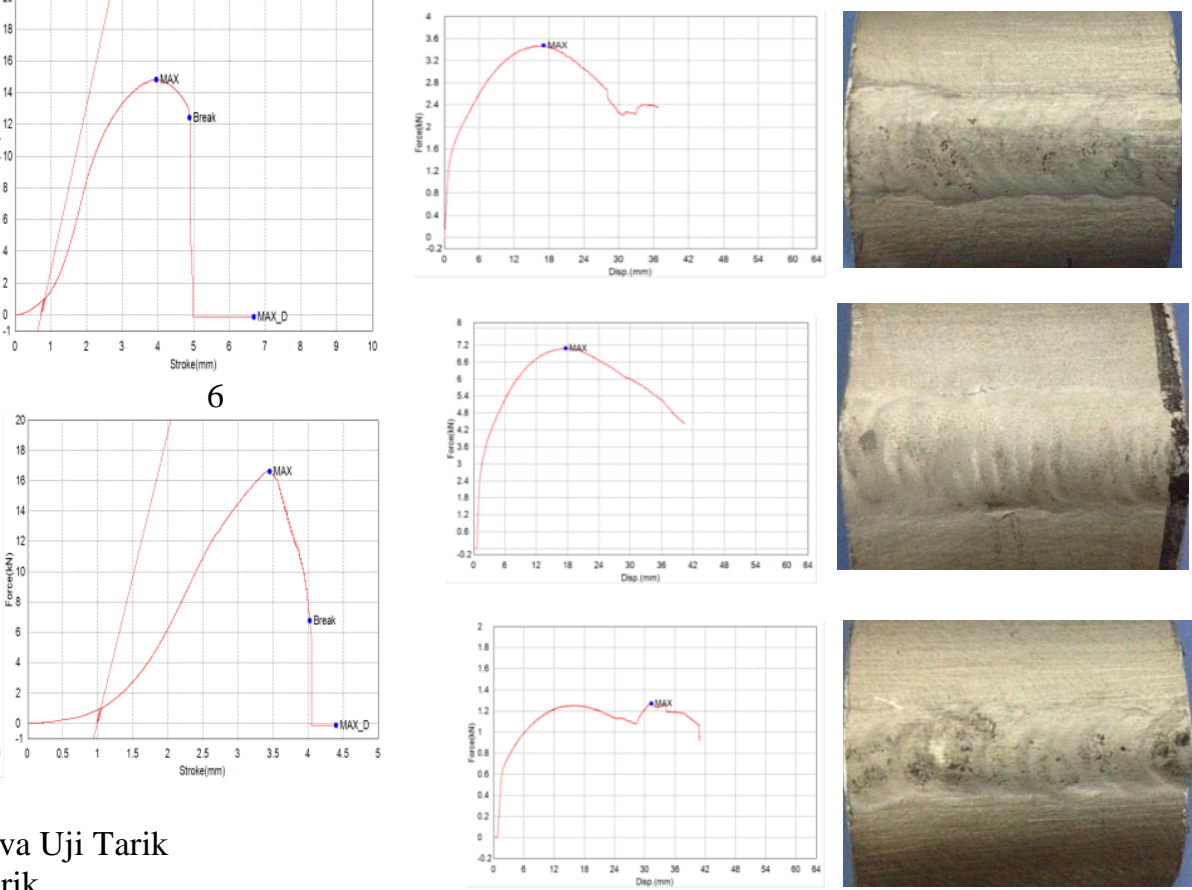

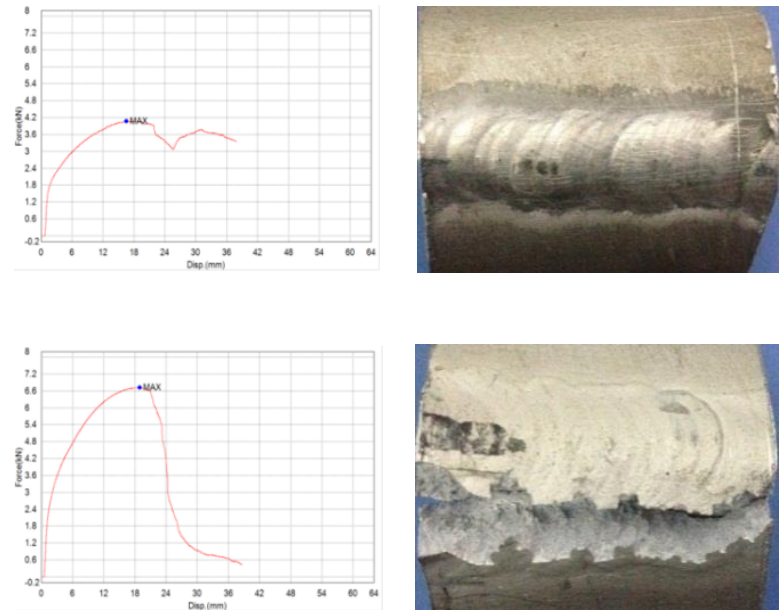

Gambar 7. Grafik dan Keadaan Uji Tekuk

Tabel 15. Analisis data uji tekuk

\begin{tabular}{|c|c|c|c|}
\hline Part & Posisi & $\begin{array}{c}\text { Tegangan } \\
\text { Maksimum }\end{array}$ & Patah \\
\hline $3 \mathrm{~mm}$ & $1 \mathrm{G}$ & $1,34640 \mathrm{kN}$ & - \\
\hline $5 \mathrm{~mm}$ & $1 \mathrm{G}$ & $3,47548 \mathrm{kN}$ & - \\
\hline $8 \mathrm{~mm}$ & $1 \mathrm{G}$ & $7,09047 \mathrm{kN}$ & - \\
\hline $3 \mathrm{~mm}$ & $3 \mathrm{G}$ & $1,27149 \mathrm{kN}$ & - \\
\hline $5 \mathrm{~mm}$ & $3 \mathrm{G}$ & $4,06923 \mathrm{kN}$ & - \\
\hline $8 \mathrm{~mm}$ & $3 \mathrm{G}$ & $6,71902 \mathrm{kN}$ & Weld Metal \\
\hline
\end{tabular}

Dari data di atas menunjukan bahwa tegangan tertinggi yang dapat dicapai ketika uji tekuk terjadi pada material tebal $8 \mathrm{~mm}$ posisi $1 \mathrm{G}$ dengan tegangan maksimum mencapai 7,09047 $\mathrm{kN}$ dan material tidak mengalami patah ketika berada pada tegangan maksimum. Sedangkan tegangan maksimum terendah yang dapat dicapai ketita uji tekuk terjadi pada material $3 \mathrm{~mm}$ posisi $3 \mathrm{G}$ dengan angka $1,27149 \mathrm{kN}$ namun material tidak mengalami patah ketika berada pada titik tegangan maksimum. Selain itu, material $8 \mathrm{~mm}$ posisi 3G mencapai titik tegangan maksimum $6,71902 \mathrm{kN}$ tetapi keadaan material patah pada weld metal ketika berada pada titik tegangan maksimum. Hal ini menunjukan bahwa kekuatan las pada material $8 \mathrm{~mm}$ posisi $3 \mathrm{G}$ sangan rendah, data yang sama juga terdapat pada pengujian tarik material $8 \mathrm{~mm}$ posisi $3 \mathrm{G}$ yang mencapai titik tegangan hanya pada angka $16,6 \mathrm{kN}$ dan renggangan maksimum hanya menunjukan angka 4,1 $\mathrm{mm}$ serta material patah pada bagian weld metal.

Dari pengujian-pengujian yang telah dilakukan dapat ditarik kesimpulan bahwa pengaruh penerapan WPS (Welding Procedure Specification) al 6005 tipe butt joint terhadap pengelasan sambungan al 6061 terjadi pada posisi pengelasan yang berbeda, hal itu ditunjukan pada ke-4 pengujian yang telah dilakukan dan data pengujian menunjukan hasil yang kurang baik pada posisi pengelasan $3 \mathrm{G}$.

\section{PENUTUP}

\section{Kesimpulan}

Setelah dilakukan uji pada aluminium 6061 hasil pengelasan MIG dengan menggunakan WPS (Welding Procedure Specification) Aluminium 6005 yang dilakukan di Laboratorium Teknik Mesin Universitas Muhammadiyah Malang dan PT. Bromo Steel Pasuruan, maka dapat ditarik beberapa kesimpulan sebagai berikut:

WPS (Welding Procedure Specification) Al 6005 standar ISO dapat digunakan untuk pengelasan material Al 6061 dengan menggunakan parameter yang sama dan juga menggunakan welder.

Hasil pengujian cacat dalam dengan menggunakan radiography test aluminium 6061 dengan variasi posisi pengelasan 1G (Flat) dan 3G (Vertikal) serta pada ketebalan $3 \mathrm{~mm}, 5 \mathrm{~mm}$ dan $8 \mathrm{~mm}$ menunjukan hasil berbeda. Densitas tertinggi dihasilkan oleh pengelasan posisi $1 \mathrm{G}$ pada tebal material $5 \mathrm{~mm}$ dengan densitas cahaya mencapai 2,86. Sedangkan, Densitas terendah dimiliki oleh pengelasan posisi $3 \mathrm{G}$ pada material $3 \mathrm{~mm}$ dengan densitas cahaya 2,41. Cacat berupa porositas terjadi hampir pada semua material pengelasan baik posisi $1 \mathrm{G}$ maupun $3 \mathrm{G}$ namun cacat berupa Incomplete Fusion hanya terjadi pada semua pengelasan dengan posisi 3G. Sedangkan hasil pengujian cacat luar dengan menggunakan cairan penetrant menunjukan porositas terjadi hampir pada semua posisi pengelasan namun cacat incomplete fusion terjadi hanya pada posisi pengelasan 3G dengan letak lokasi cacat berada pada bagian akar lasan.

Kekuatan material las dengan uji tarik dan tekuk menunjukan rata-rata kekuatan tertinggi berada pada posisi pengelasan $1 \mathrm{G}$ untuk semua ketebalan, dan kekuatan terendah terjadi pada material las dengan posisi $3 \mathrm{G}$ pada tebal $8 \mathrm{~mm}$.

WPS al 6005 yang diterapkan dalam pengelasan al 6061 menunjukan hasil yang cukup baik dan pada standar penerimaan pengujian material menunjukan angka diatas penerimaan untuk posisi pengelasan $1 \mathrm{G}$.

\section{Saran}

Selanjutnya dari pembahasan penelitian ini, dapat dirangkum beberapa saran yang berkaitan dengan penelitian ini adalah sebagai berikut:

Pada proses pengelasan material oleh welder harus diperhatikan sertifikasi posisi pengelasan yang dimiliki oleh welder untuk hasil yang lebih baik.

Pada penelitian berikutnya diharapkan bisa membandingkan variasi arus pada material yang sama. 


\section{DAFTAR PUSTAKA}

Aluminium Federation of Southern Africa. 2004. TheWelding Of Aluminium MIG \& TIG Fusion. Second Edition AFSA.

Artanto, Indra Dkk. 2015. Analisa Kekuatan Tarik Dan Komposisi Bahan Paduan Aluminium Limbah Ac Mobil Dengan Metode Metal Casting Untuk Bahan Jendela Kapal. Program Studi S1 Teknik Pekapalan, Fakultas Teknik, Universitas Diponegoro Jurnal Teknik Perkapalan - Vol. 3, No.2.

ASM Metals Handbook, 2001. Desk Edition Volume 2, Volume 6, Volume 7, Volume 8, Volume 10.

Dewanto, Anggoro P. 2016. Analisa Kekuatan Mekanik Sambungan Las Metode MIG( Metal Inert Gas) DanMetode FSW( Friction Stir Welding) 800 Rpm Pada Alumunium Tipe 5083. Jurusan Teknik Perkapalan, Fakultas Teknik, Universitas Diponegoro. Jurnal Teknik Perkapalan - Vol. 4, No.3.

Engineer Division Handbook. 1999. Aluminium Alloy 6061. Aluminium City (Pty) Limited. Technical Data Page T9.

Hiyazi, Dr. Ala. Radiographic Testing. Introcdution To Non-Destructive Testing Tecnique.

Krishna Muku, Made. 2009. Kekuatan Sambungan Las Aluminium Seri 1100 dengan Variasi Kuat Arus Listrik Pada Proses Las Metal Inert Gas (MIG). Jurusan Teknik Mesin, Universitas Udayana, Kampus Bukit Jimbaran Badung - Vol. 3, No.1.

Moore, Albert J. 2010. Think of a welding procedure specification as the recipe for successful welds. What Are Welding Procedure Specifications, SPRING 15.

Qazi,Hafiz Abdul A. 2017. Study of Verification and Validation of Standard Welding Procedure Specifications Guidelines for API 5L X-70 Grade Line Pipe Welding. Quality Control Health and Safety Environment, Pakistan. Oil and Gas Research ISSN: 2472-0618

Sarwar, Muhammad Dkk. 2016. Proposed Guidelines For Welding Procedures To Ensure Quality Welding Of Creep Strength Enhanced Ferritic (CSEF) Materials. Mechanical Engineering Department, Universiti Teknologi Petronas, Bandar Seri Iskandar, Tronoh, Perak, Malaysia. ARPN Journal of Engineering and Applied Sciences, ISSN 1819-6608.

Steel Industry Guidance Notes. 2010. Welding Procedure Specifications (WPSs).

Tata Steel Handbook. Guide To Weld Inspection For Structural Steelwork. The British Contructional
Steelwork Association, Number 54/12, ISBN 10: 1 85073-064-4.

Welding Handbook. Welding Science And Technology. American Welding Society Ninth Edition Volume 1, 550 N.W. LeJeune Road Miami, FL 33126.

Welder's Visual Inspection Handbook. 2013. Visual Inspection Responsibilities and Tecnique. 